\title{
Alternative Mitigation to Counter Resource Losses from the Lake Cumberland Drawdown, Kentucky
}

\author{
Valerie J. McCormack $\odot$ and Kary Stackelbeck $\odot$
}

\section{ABSTRACT}

This article presents a case study of the process of developing and implementing mitigation as the result of adverse effects to cultural resources from the drawdown of Lake Cumberland, Kentucky. Signs of a dam failure in early 2007 triggered the U.S. Army Corps of Engineers (Corps) to implement the emergency drawdown. While the drawdown prevented a life safety catastrophe, it created a new erosion zone and exposed archaeological sites to looters. When it became clear that conventional Section 106 procedures to identify and evaluate these endangered archaeological resources were not an option, alternative and creative mitigation became a necessary approach for the Corps to meet its obligations under the National Historic Preservation Act. This article discusses the creative brainstorming among the Corps, Kentucky state historic preservation officer, and tribes that led to three alternative mitigation measures aimed at educational outreach, raising public awareness, and staff training. Furthermore, the article identifies challenges encountered during the implementation of the mitigation measures. Through the presentation of our mitigation journey, we share some of our lessons learned to improve awareness of the challenges and successes one may encounter during the execution of such alternative measures.

Keywords: Section 106, National Historic Preservation Act, alternative mitigation, Lake Cumberland, Kentucky Heritage Council, Kentucky Archaeological Survey, U.S. Army Corps of Engineers, Project Archaeology, Federal Law Enforcement Training Centers

Este documento presenta un estudio de caso del proceso de desarrollo e implementación de el atenuantecomo resultado de los efectos adversos a los recursos culturales de la reducción del lago Lake Cumberland en el estado de Kentucky, los Estados Unidos. Las señales de una falla en la presa a principios de 2007 provocaron que el Cuerpo de Ingenieros del Ejército de los Estados Unidos (Cuerpo) implementara la reducción del nivel del agua en el lago en una manera de emergencia. Si bien la reducción evitó una catástrofe de seguridad de la vida, creó una nueva zona de erosión y expusó los sitios arqueológicos a los actividades no autorizadas. Cuando quedó claro que los procedimientos convencionales de la Sección 106 para identificar y evaluar los recursos arqueológicos que estan en peligro no eran una opción, la mitigación alternativa y creativa se convirtió en un enfoque necesario para que cumpliera con sus obligaciones bajo la Ley Nacional de Preservación Histórica. Este documento discute la lluvia de ideas creativas entre el Cuerpo, el oficial de la preservación histórica del estado de Kentucky, y las tribus que conducen a tres medidas alternativas de mitigación destinadas a la divulgación educativa, la sensibilización del público y la capacitación del personal. Además, el documento identifica los desafíos encontrados durante la implementación de las medidas de mitigación. A través de la presentación de nuestraexperiencia, con este processo especificado, compartimos algunas lecciones aprendidas para mejorar el conocimiento de los desafíos y éxitos que uno puede encontrar durante la ejecución de tales medidas alternativas.

Palabras claves: Sección 106, la Ley Nacional de Preservación Histórica, la mitigación alternativa, Cuerpo de Ingenieros del Ejército de los Estados Unidos, Consejo de Patrimonio de Kentucky, Encuesta Arqueológica de Kentucky, Proyecto de Arqueologia

In January 2007, the Nashville District of the U.S. Army Corps of Engineers (Corps) confronted a potentially catastrophic failure of Wolf Creek Dam in central Kentucky. The Nashville District and the Kentucky Heritage Council (KHC) engaged an alternative mitigation strategy to address the effects of the management on archaeological sites. Now that the implementation is complete, we are in a position to share some lessons learned with agencies, organizations, tribes, companies, and the public that may be considering engaging in alternative mitigation strategies.
Here, we present the project background that constituted the undertaking requiring National Historic Preservation Act Section 106 compliance (54 USC 306018). We discuss some of the challenges we faced given the emergency that influenced our decision to forgo conventional data recovery methods and pursue alternative mitigation. Following review of the planning and collaboration that led to the ultimate agreement, we present some of the challenges we faced during the mitigation implementation. Ultimately, the mitigation emphasized educational measures.

Advances in Archaeological Practice 8(3), 2020, pp. 299-306

(C) Society for American Archaeology 2020. This is an Open Access article, distributed under the terms of the Creative Commons Attribution licence (http://creativecommons.org/licenses/by/4.0/), which permits unrestricted re-use, distribution, and reproduction in any medium, provided the original work is properly cited.

DOI:10.1017/aap.2020.24 
Finally, we conclude with some lessons learned that may assist others considering alternative or creative mitigation.

\section{EMERGENCY AT WOLF CREEK DAM}

The electronic monitoring system at Wolf Creek Dam, Jamestown, Kentucky, alerted the Corps to a potential dam failure on January 7 , 2007. Failure of Wolf Creek Dam, the largest dam east of the Mississippi River in the United States, would be catastrophic, as the dam impounds 100 miles of the Cumberland River and $7.5 \mathrm{~km}^{3}$ of water to form Lake Cumberland (Figure 1). Failure of Wolf Creek Dam would lead to more than 100 lives lost; \$2 billion in damages in Nashville, Tennessee; and significant flooding downstream along the Ohio and Mississippi Rivers. The Corps invoked emergency procedures under the National Environmental Policy Act and the National Historic Preservation Act and began the emergency drawdown of Lake Cumberland to mitigate failure risk by relieving pressure on the dam. The extended drawdown spanned January 2007 to March 2013 (USACE, LRN 2007; Zoccola and Santillan 2013).

Lake Cumberland, like many dams and reservoirs, is managed through an annual seasonal operational drawdown. The reservoir's summer pool elevation is approximately $220.0 \mathrm{~m}$ above sea level (asl). Beginning in August, the reservoir is drawn down to $210.3 \mathrm{~m}$ asl through the winter. In late spring the cycle begins again as water flowing into the reservoir is held back to create the summer pool (USACE, LRN 2011).

This cyclical management serves to meet multiple purposes including flood control, hydropower production, and recreational uses. While the exposure of the shoreline during an annual operational drawdown is a familiar situation to many Section 106 practitioners working with water resource agencies, the Lake Cumberland emergency drawdown differed in a number of ways.

First, the Corps needed to release water from the reservoir to relieve pressure on the dam, and they needed to release it quickly. The Wolf Creek emergency was a life safety issue. There was no time to consider the effects of the emergency drawdown on cultural and natural resources. Second, this emergency drawdown was not within the normal operating range of 210.3$220.0 \mathrm{~m}$ asl. The emergency drawdown required the reservoir to be dropped to $207.3 \mathrm{~m}$ asl, a full $3 \mathrm{~m}$ below the lowest annual operating point. Located within an eroded plateau with a dendritic drainage system, Lake Cumberland inundates hundreds of tributary streams and creeks to create a $2,020 \mathrm{~km}$ long shoreline (USACE, LRN 2007). While a vast majority of the shoreline is extremely steep, in portions of the upper reservoir the shoreline includes floodplains, terraces, and other landforms with a high potential for archaeological sites. The emergency drawdown exposed land that had been inundated and inaccessible for more than half a century.

\section{CALL TO ACTION}

Concurrent with the declaration of a life safety emergency, the Corps invoked emergency procedures under 36 CFR 800.12 to comply with Section 106 (USACE, LRN 2007). Archaeologists at the Corps and $\mathrm{KHC}$ identified the immediate need for archaeological survey of the newly exposed lands. This initial consultation resulted in the application of conventional historic property identification methods. Background research and site file reviews revealed that very little was known of archaeological resources within the emergency drawdown zone (207.3-210.3 m asl).

Previous archaeological investigations at Lake Cumberland stemmed from the 1947 pre-inundation survey (Haag 1947) and various surveys carried out for Section 106 compliance. While the previously collected data did not provide a statistically sound sample of site chronologies, types, or distribution, they did indicate that sites located within the annual operational drawdown zone (220.0-210.3 m asl) were severely eroded and lacked integrity (Bradbury 1998:65; Schock 1997:31). However, the condition of sites located within the emergency drawdown zone (207.3$210.3 \mathrm{~m}$ asl) remained unknown. The initial archaeological survey began in April 2007 with the goal to characterize the impacts on archaeological sites resulting from the drawdown. Secondary surveys and site evaluations began in March 2009.

The contracted firm, URS, referenced historic U.S. Geological Survey topographic maps, detailed Corps Cumberland River pre-inundation survey maps, and post-emergency aerial photography to identify areas of the exposed shoreline with the greatest potential to contain archaeological sites. Lake Cumberland is a deep lake. The original floodplain lies below $60 \mathrm{~m}$ of water in some locations. Steep slopes and cliff faces characterize a large portion of the shoreline, as the shoreline intersects the dissected peneplain. With the goal to identify archaeological sites within the emergency drawdown zone, the survey focused on areas with exposed floodplains and terraces. These areas are present in the upper reaches of the reservoir and tributary streams where reservoir depths are shallow. The archaeological survey focused on a $34 \mathrm{~km}$ subset of the overall lake shoreline. URS attempted to revisit 53 previously recorded sites and survey lands with topographic potential for past occupation (Figure 2). The firm relocated nine of the 53 previously recorded sites and identified 38 new sites. Thirty-one of these sites were severely eroded and lacked soil. Therefore, the Corps and KHC determined these 31 sites as not eligible for listing on the National Register of Historic Places due to lack of integrity (Polglase et al. 2011). Initially, 16 sites were categorized as unevaluated and required additional information to determine their National Register status.

The data from the survey revealed that the 50 years of wave action and reflection within the emergency drawdown zone had in fact eroded soils. In a region where sites, especially precontact sites, are typically identified through shovel test pit sampling, most sites on Lake Cumberland's shoreline were identified through surface inspection. Furthermore, surface inspection revealed that most of the shoreline consisted of mineral soils, which eliminated the need for any subsurface testing.

Initially, National Register of Historic Places site assessments began at four sites. Two sites retained sufficient integrity to meet eligibility criteria (U.S. Department of the Interior, National Park Service 1995). The remaining two sites revealed the characteristic lack of soil observed along the majority of the shoreline. Questions related to the information potential from artifact distributions within the eroded sites revealed that little useful data could be gleaned from site remnants. Although it is an extremely small sample, site locations within landforms and wave action zones appeared to be critical factors leading to site preservation and retention of integrity. 


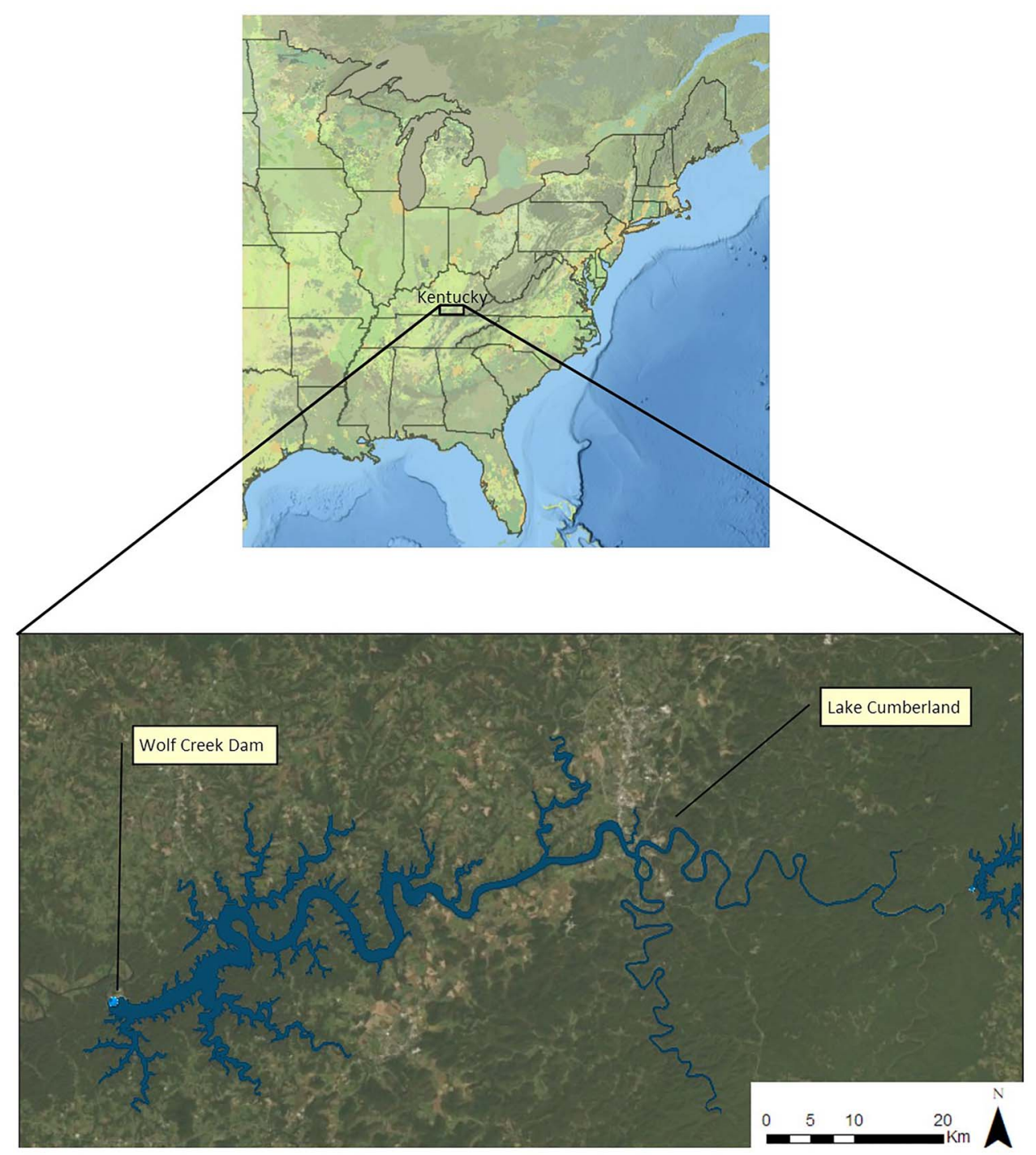

FIGURE 1. Location of Lake Cumberland within Kentucky. Note the inundation of many tributaries creating the lengthy shoreline.

In addition to the impacts resulting from erosion, the survey also identified clear evidence of surface collecting at exposed sites. Would-be looters appeared to capitalize on the rare opportunity to access sites that were otherwise submerged. Given the lack of soils, looting behavior included scouring the surface, flipping rocks, creating "goody" piles, and presumably removing arrowheads, projectile points, or other finished tools (Figure 3). Unfortunately, the reservoir's size, its multiple hidden coves, and the small attendant staff inhibit adequate patrol of the land-a situation that left these resources vulnerable to collecting.

\section{PURSUIT OF ALTERNATIVE MITIGATION}

As the results of the field investigations became available in report form (Polglase et al. 2011), new staff (the coauthors) joined the Corps (Valerie McCormack) and the KHC (Kary Stackelbeck). The project conditions were rapidly changing. Work on Wolf Creek Dam was nearing completion, and reservoir levels were rising, nearing the annual operating winter pool of $210.3 \mathrm{~m}$ asl. Continued access to the sites within the drawdown zone became questionable. Adverse effects to selected sites were clearly documented; however, attempting to address those effects through conventional methods, such as data recovery, was unrealistic. Consultation with our tribal partners, Absentee Shawnee Tribe of Oklahoma, Cherokee Nation, Chickasaw Nation, Eastern Band of Cherokee Indians, Eastern Shawnee Tribe of Oklahoma, Shawnee Tribe, and United Keetoowah Band of Cherokee Indians, revealed similar perspectives and an inclination to favor alternative mitigation in lieu of excavation of the threatened sites and subsequent specialized analyses, documentation, and curation.

As we focused on the development of a memorandum of agreement (MOA) under 36 CFR 800.6, for legal compliance, we began to explore alternatives to conventional treatment. As the Advisory 


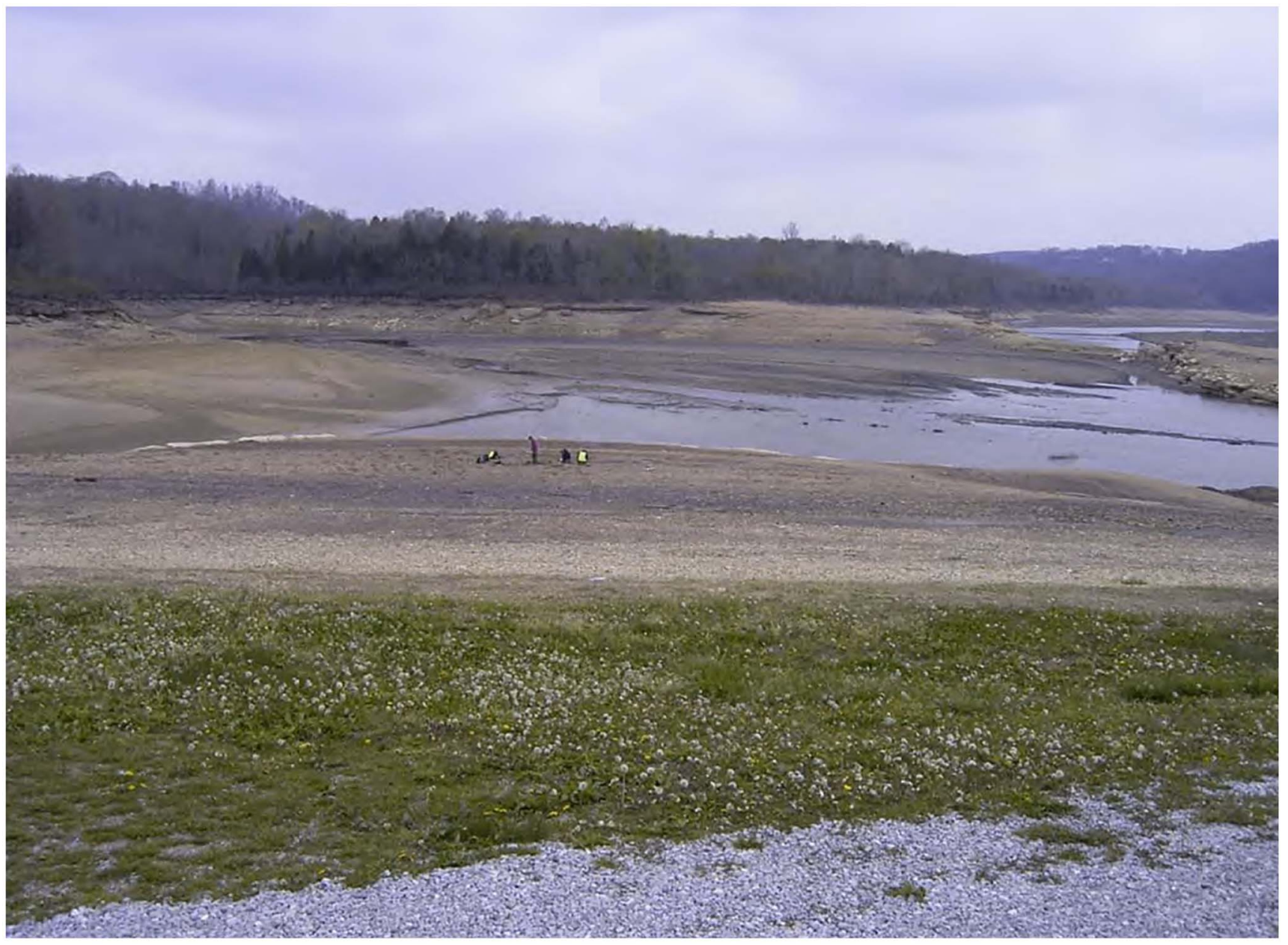

FIGURE 2. Archaeologists examining the exposed shoreline of Lake Cumberland. The archaeologists are standing on land that was inundated from 1952 to 2007 (courtesy of the U.S. Army Corps of Engineers, Nashville District, from Polglase et al. 2011; used with permission).

Council on Historic Preservation notes, there is no predetermined outcome for the resolution of adverse effects. Additionally,

"alternative" or "creative" mitigation approaches may be implemented, but they should be reached through consultation and represent the broader public interest (Advisory Council on Historic Preservation 2020).

While the pursuit to develop alternative mitigation forced us into unfamiliar territory, consulting parties were uniformly committed to this approach for the Lake Cumberland drawdown project. To help us navigate through the unknown we borrowed from the Corps Planning Process. The Planning Process, used by multiple federal agencies to plan water- and land-related resource implementation studies (U.S. Army Corp of Engineers 2000; U.S. Water Resources Council 1983; Yoe and Orth 1996), identifies and funnels measures through screens to help identify the most effective solution to a problem.

The use of the Planning Process allowed for structured decision making with the flexibility to arrive at a solution that was unique to the Lake Cumberland problem. Iterative in nature, the Planning
Process flows through several steps. Once the subject problems and opportunities are assessed, the process moves to identifying a range of alternative solutions. The evaluation and comparison process helps to identify which plans would best resolve the problems. Ultimately, the process ends with selection and implementation. Our loose application of the Planning Process paired well with the Section 106 process, which is designed to engage consulting parties in the decision-making process.

Highly engaged consulting parties were prepared to work collaboratively on this project, but the process was not without challenges. Geographic proximity to one another presented the first challenge. Consulting parties were dispersed across several states, and no one lived in close proximity to Lake Cumberland. Preexisting relationships eased the consultation discussions.

Monthly conference calls allowed us to progress toward solutions. At the time, internet connections were poor, and web meetings were not an option.

For our situation at Lake Cumberland, the outcome of the Planning Process equated to the mitigation measures that would 


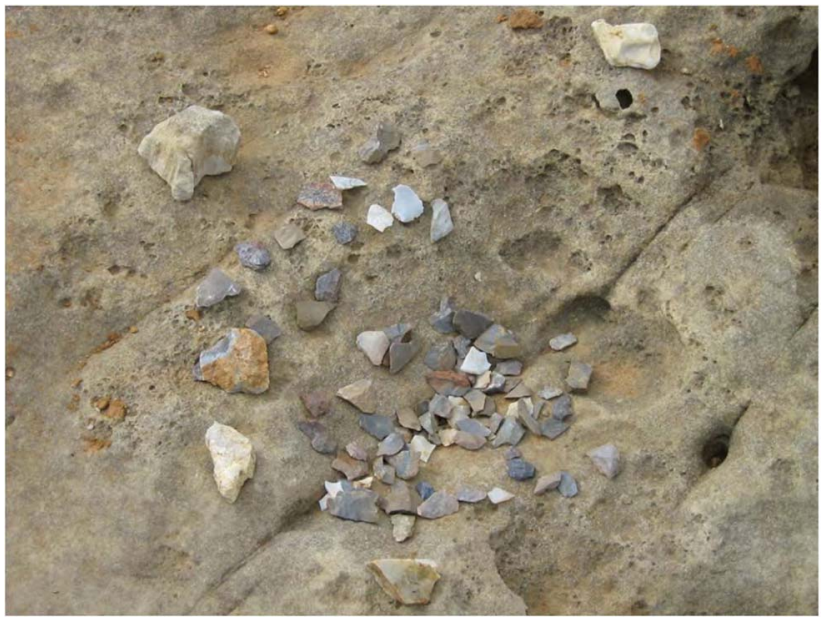

FIGURE 3. Example of a "goody pile" commonly encountered at exposed archaeological sites during the Lake Cumberland drawdown. These piles demonstrate unauthorized collecting that occurred during the drawdown (courtesy of the U.S. Army Corps of Engineers, Nashville District, from Polglase et al. 2011; used with permission).

be incorporated into the MOA. Through the assessment of the situation, available data, and expected future conditions at Lake Cumberland, we identified looting and site destruction as the main problems facing cultural resources in the project area.

As we began formulating alternative plans, we cast a wide net. Multiple ideas arose as mitigative measures, including (1) reanalyzing Haag's 1947 data, (2) training tribal members to conduct archaeological survey, (3) developing avocational partnerships, (4) training teachers and students about civic responsibility in cultural resource stewardship, (5) Archaeological Resources Protection Act (ARPA) training for local law enforcement and Corps park rangers, and (6) public outreach through website or video development. Evaluation of these possible measures in relation to the project needs allowed us to eliminate those that were not a good fit. We funneled the measures down to those we determined to be best suited and most feasible: (1) educating educators, (2) developing an educational video, and (3) educating rangers and law enforcement partners. We executed an MOA just as the dam rehabilitation was completed and Lake Cumberland returned to its historic operating pools of $220.0-210.3 \mathrm{~m}$ asl.

\section{THE MITIGATION}

Collectively, the consulting parties agreed that education could help combat looting. We recognized that oftentimes it is the lack of understanding about archaeology that leads to inadvertent damage, especially through activities such as surface collection. Education could help improve awareness about the resources and foster a sense of responsibility for their protection. However, to be successful, we would need to target multiple audiences and have effective delivery methods.

The KHC and Kentucky Archaeological Survey (KAS) had strong preexisting public archaeology programs. This presented a situation where we could capitalize on the local public archaeology infrastructure. In particular, we recognized the prior successes of Kentucky's state Project Archaeology program and identified that bringing it to the Lake Cumberland area could help educate children and educators alike. Additionally, KAS had drafted Project Archaeology: Investigating a Shotgun House (Henderson et al. 2016) as a state-level supplement to Project Archaeology: Investigating Shelter (Letts and Moe 2009), a curriculum for fourth to sixth grade. Kentucky's shotgun house curriculum required piloting, an activity that paired well with our needs for an educational product. Capitalizing on our mutual goals, we defined the first measure: hold a weeklong teacher training for fourth- to sixth-grade social studies teachers for the counties around Lake Cumberland.

Beyond the need for general education about archaeology, we also acknowledged the continued need to inform the public about past native presence in Kentucky-due in part to a longheld myth that indigenous people never truly lived in the commonwealth. As with other states where aboriginal groups were removed from their ancestral homelands, it can be difficult for today's populations to connect with past peoples and cultures. Continuing with the education theme, we chose to develop a Public Broadcasting Service-style video featuring Cherokee, Shawnee, and Chickasaw peoples discussing their connections with Kentucky. The intent was to complement the Investigating Shelter unit by providing a quality educational video with fourth graders as a target audience.

Finally, we identified a need to better educate Corps rangers and partners in county sheriff offices and municipalities who are otherwise responsible for assisting in the enforcement of cultural resource protection laws on Corps-owned property. To accomplish this goal, we initially intended to educate law enforcement officers in both groups by hosting a weeklong ARPA class. However, the lack of congressional authorization allowing the Corps to train local law enforcement partners became a constraint that we could not overcome. A reevaluation of what we could do guided us to our third mitigation measure to train Corps rangers through the Federal Law Enforcement Training Centers (FLETC) Archeological Resources Protection Training Program and a scaled-down lunch and learn program for local law enforcement.

\section{IMPLEMENTATION CHALLENGES}

By the time we completed the MOA, we thought that we had overcome the difficult tasks and were in the homestretch. New challenges lurked ahead. Implementing the measures proved to be much more difficult than we could have imagined and substantially more difficult and complex than conventional data recovery.

Federal contracting law was a reoccurring hurdle. Although the Corps Contracting Office was consulted during the formulation of the mitigation, annual updates to the Federal Acquisition Regulation changed the contracting environment.

The success of the teacher training hinged on the involvement of the KAS. During the MOA development, it was clear that the training would best be directed by KAS. The memorandum of 
understanding (MOU) "Continuation of the Cooperative Ecosystem Studies Units Network" provides a mechanism for federal agencies to access subject matter experts (SMEs) in academia. While the intent of this MOU is to allow federal agencies to access academic support, it has a number of distinct Corps-specific requirements. While many federal agencies could have easily used this MOU as a mechanism to hire the KAS, the additional requirements made access more difficult for the Corps. Although the proposal passed through several initial approval chains, it was ultimately rejected for not meeting all the Corps-specific MOU requirements. These lengthy reviews delayed implementation of the teacher training for a year. The execution strategy shifted to issuing a sole-source contract with the UK-KAS. While sole sourcing a contract is not impossible, rigorous justification is required. Had we known from the outset the challenges that would be faced with the MOU, we likely would have opted for the sole sourcing approach much sooner to avoid the delays.

With a contract finally in place, UK held a weeklong academy called "Making History Local: An Inquiry-Based Approach" in July 2014. Fourteen elementary and middle school teachers from the counties surrounding Lake Cumberland were immersed in a Kentucky-based archaeological curriculum. The training involved teaching the Project Archaeology curriculum Investigating Shelter (Letts and Moe 2009), including the Kentucky-specific component, Investigating a Shotgun House (Henderson et al. 2016). The training allowed KAS and UK to conduct a longitudinal assessment of the shelter unit and compile data geared toward earning approval for certification to implement the program statewide. The following year the annual curriculum for 121 students, mainly in low-income rural communities, was enriched through this archaeological content (Henderson 2015). Indeed, the Society for American Archaeology honored the KAS in 2018 by bestowing the Award for Excellence in Public Education in part for its work on programs like this one.

The ARPA training was the next mitigation training to be implemented. The Nashville District selected FLETC to train park rangers through its excellent Archeological Resources Protection Training Program. On the surface, one federal agency training another federal agency might seem to be a simple task. However, the Economy Act (31 USC 1535) requires several time-consuming steps to successfully transfer funds between agencies. After a year of patience and perseverance, FLETC trained 18 park rangers, three archaeologists, and two lawyers in fall 2017. This effort has also led to a continued interest in combating looting by park rangers. Additional condensed trainings with the assistant U.S. attorney were conducted for all park rangers the following winter.

The last mitigation measure-production of the educational video-presented its own challenges. Once again, contracting was difficult. Corps contracting officials viewed the video as a promotional product and not an educational product as required by mitigation. In keeping with the Federal Acquisition Regulation, the Contracting Office's first opinion was that a lowest-bid contract would be most appropriate and meet a requirement for full and open competition. The hours and meetings advocating for alternative contract selection criteria and the development of the scope of work seemed endless. The resulting request for proposals was not exactly what we initially envisioned, but it allowed the mitigation to move forward.
Technically, the bid would have to be "demonstrably sufficient." The structure of the request for proposals prevented specific naming of the archaeological SME who would be involved in the video production. This precluded evaluation of a given expert and his or her qualifications as part of the process of vetting proposals.

This structure created an uneasy situation that allowed the video production company to choose an SME who met contractual requirements but was at odds with the federally recognized tribes who were centrally involved in the video production. This situation negatively impacted what had been an excellent collaborative relationship with the consulting tribes and development of the video content. Upon notification of the situation, the Corps was able to intervene and have a new SME installed. This delayed the production process but also necessitated substantially greater investment of effort by the Corps cultural resource staff to bring the project to completion.

Despite these challenges, the video is now complete. We distributed it directly to teachers in the area of Lake Cumberland, aired it on Kentucky Educational Television, and present it on the Corps YouTube channel. Interested readers can find it at https:// www.youtube.com/watch?v=2KSRM5CI_QM.

Workload also presented challenges. Given other responsibilities, previous commitments, and a budgetary environment of sequestration, time allowed for implementation of only one measure at a time. This resulted in drawing out the completion of the various stipulations of the MOA much longer than expected.

Twelve years transpired from the declaration of the emergency drawdown to the distribution of the video. Consulting parties experienced multiple staff changes, and interest in the project vacillated. With completion of the mitigation measures, we resolved to reflect on the high and low points of the overall endeavor.

\section{LESSONS LEARNED}

Despite the many challenges, we think that the benefits of the overall project have been proportionate to the difficulties. Nevertheless, we have learned some lessons that are worth imparting so that others may act with awareness if they pursue this approach.

First, allow time to develop and implement the measures. Disavow yourself of any expectations of quick returns. An overarching framework, such as the Planning Process, may be useful in structuring decision points. However, the process may take some time-especially when the views and input of multiple parties are necessary. If a project deadline is looming, or if any of the consulting parties are uncomfortable with the possibility of substantial time lag between execution of the MOA and implementation of the stipulations, then an alternative approach may not be appropriate.

At the time we developed our mitigation, we heavily depended on teleconferences for communication. Internet access and network connectivity were not reliably available at the time. Today, technological advances and improved network capabilities 
provide better options for long-distance communication and collaboration. We recommend exploring these tools if they are not already part of your communication tool kit.

Second, be prepared to educate (and reeducate) others about the purpose and intent of the project. Do not expect the same staff that started with the project to be there at the end. In this case, the original project began with our predecessors. During the development of the mitigation measures, we were a group of passionate cultural resource management practitioners collaborating on the most appropriate means to account for the loss of significant resources. As we shifted from development of the MOA to implementation, the excitement and passion that drove creativity during the formulation began to wane. New emergencies and priorities emerged within offices, which diverted the team's attention and ability to maintain momentum. As time passed, staff changed. New staff lacked investment in the mitigation measures, leaving a smaller team to carry the torch.

Similarly, be prepared for staff changes within your agency. Some colleagues may be willing to rise to a challenge more than others. Taking the time to educate colleagues on the goals of the project may help them understand and be more willing to support a difficult but purposeful need.

Third, in hindsight, the execution of a risk analysis (Yoe 2012) may have helped us either foresee some of these challenges or be better prepared for action that might have more readily adjudicated the situation. In similar situations, it would be beneficial to have a matrix to identify anything that could impede execution of a project in place.

Finally, if you do not believe that you or your agency can honestly commit to completing the alternative or creative measures, then it is better not to embark down this path (unless of course you have no choice). If you do decide to pursue such ambitious, nontraditional measures, engage staff of the many offices that might be involved in the implementation early in the planning process. Additionally, act to incorporate new staff into the project when personnel changes occur.

For many Section 106 projects that cannot avoid impacts to significant archaeological sites, traditional data recovery may continue to be the standard practice-and appropriately so. However, we encourage those in the cultural resource management community to be open to the rewards (and challenges) of pursuing other, less traditional approaches to mitigation when the conditions warrant it, the consulting parties are supportive, and they serve the public interest.

\section{Acknowledgments}

The products of the Lake Cumberland drawdown are the result of cooperative support from the U.S. Army Corps of Engineers and the Kentucky Heritage Council. Tribal partners in this effort include the Absentee Shawnee Tribe of Oklahoma, Cherokee Nation, Chickasaw Nation, Eastern Band of Cherokee Indians, Eastern Shawnee Tribe of Oklahoma, Shawnee Tribe, and United Keetoowah Band of Cherokee Indians. The memorandum of agreement was developed with the particular insight and experience shared by Gingy Nail and Ladonna Brown (Chickasaw Nation), Robin DuShane (Eastern Shawnee Tribe of Oklahoma),
Lisa LaRue (United Keetoowah Band of Cherokee Indians), and Gwyn Henderson (Kentucky Archaeological Survey). Corps project managers and supervisors David Hendrix, Don Getty, Doug DeLong, and Tim Higgs showed great patience as we pushed to meet particular standards as we implemented the mitigation. Jesse Lindsey and Ladonna Brown (Chickasaw Nation); Johi Griffen, Beau Carroll, and Miranda Panther (Eastern Band of Cherokee Indians in North Carolina); Second Chief Ben Barnes and Jeremy Turner (Shawnee Tribe); Bill Huser (Kentucky Heritage Council); Stephen Warren (University of lowa); the 2019 fourthgrade class of Glendover Elementary School; and Cody Pyles (U.S. Army Corps of Engineers) assisted with the video production. Gwynn Henderson and David Pollack (Kentucky Archaeological Survey) provided critical support and feedback for more than a decade throughout the entire project. Nick Laracuente at the Kentucky Heritage Council helped to wrap up the loose ends and see the project through to the end. Finally, we appreciate John Douglass and Shelby Manney for inviting us to participate in the "Creative Mitigation Measures for the Section 106 and NEPA Process" symposium at the 84th Annual Meeting of the Society for American Archaeology and continued effort in the development of this article. Archaeological investigations by URS Group Inc. were conducted under a direct contract with the U.S. Army Corps of Engineers on federal landholdings. Therefore, no permits were issued.

\section{Data Availability Statement}

No original data are presented in this article. Reports of archaeological investigations cited in this article are on file at the U.S. Army Corps of Engineers, Nashville District, and the Kentucky Office of State Archaeology.

\section{REFERENCES CITED}

Advisory Council on Historic Preservation

2020 Reaching Agreement on Appropriate Treatment. Electronic document, https://www.achp.gov/Section_106_Archaeology_Guidance/Questions\% 20and\%20Answers/Reaching\%20agreement\%20on\%20Appropriate\% 20Treatment, accessed April 4, 2020.

Bradbury, Andrew P.

1998 An Archaeological Survey of Portions of Wolf Creek/Lake Cumberland, Russell County, Kentucky. Cultural Resource Analysts. Submitted to the U.S. Army Corps of Engineers, Great Lakes and Ohio River Division, Nashville District. Copies available from the U.S. Army Corps of Engineers, Nashville District, Nashville, Tennessee.

Haag, W. G

1947 Preliminary Appraisal of the Archaeological Resources of Wolf Creek Dam and Reservoir. Bureau of American Ethnology. Copies available from the U.S. Army Corps of Engineers, Nashville District, Nashville, Tennessee. Henderson, A. Gwynn

2015 Project Archaeology Teacher Training and Classroom Implementation Project (W912P5-14-T-0012) Status Report, June 30, 2015. Kentucky Archaeological Survey. Submitted to the U.S. Army Corps of Engineers, Nashville District. Copies available from the U.S. Army Corps of Engineers, Nashville District, Nashville, Tennessee.

Henderson, A. Gwynn, M. Jay Stottman, Robin L. Jones, Linda S. Levstik, Janie-Rice Brother, Judy Sizemore, and Tom Law

2016 Project Archaeology: Investigating a Shotgun House. Montana State University, Bozeman; Kentucky Archaeological Survey, Lexington.

Letts, Cali A., and Jeanne M. Moe

2009 Project Archaeology: Investigating Shelter. Montana State University, Bozeman. 
Polglase, Chris, Alvin Banguilan, Justin Bedard, Tracy Formica, Kristin Heasley, Robert Pauline, Jagadish M. Prakash, and Suzanne Loadholt

2011 An Archaeological Reconnaissance and Assessment of Selected Drawdown Areas within the Wolf Creek Dam/Lake Cumberland Shoreline, Russell, Pulaski, Laurel, McCreary, Wayne, and Clinton Counties, Kentucky. URS Group. Contract No. W91237-08-D-0023. Submitted to the U.S. Army Corps of Engineers, Great Lakes and Ohio River Division, Nashville District. Copies available from the U.S. Army Corps of Engineers, Nashville District, Nashville, Tennessee.

Schock, Jack

1997 A Cultural Reconnaissance of Approximately 318 Acres for the Pulaski County Park Expansion in Pulaski County, Kentucky. Arrow Enterprises.

Submitted to the U.S. Army Corps of Engineers, Great Lakes and Ohio River Division, Nashville District. Copies available from the U.S. Army Corps of Engineers, Nashville District, Nashville, Tennessee.

USACE, LRN (U.S. Army Corps of Engineers, Great Lakes and Ohio River Division, Nashville District)

2007 Wolf Creek Dam/Lake Cumberland Emergency Measures in Response to Seepage. Final Environmental Impact Statement. Copies available from the U.S. Army Corps of Engineers, Nashville District, Nashville, Tennessee. U.S. Army Corp of Engineers

2000 Planning Guidance Notebook. Engineering Regulation No. 1105-2-100. Electronic document, https://planning.erdc.dren.mil/toolbox/library/ERs/ entire.pdf, accessed April 4, 2020.

U.S. Army Corps of Engineers, Great Lakes and Ohio River Division, Nashville District

2011 Lake Cumberland Master Plan Update. Copies available from the U.S. Army Corps of Engineers, Great Lakes and Ohio River Division, Nashville District, Nashville, Tennessee.

U.S. Department of the Interior, National Park Service

1995 How to Apply the National Register Criteria for Evaluation. National
Register Bulletin No. 15. Electronic document, https://www.nps.gov/subjects/nationalregister/upload/NRB-15_web508.pdf, accessed April 4, 2020. U.S. Water Resources Council

1983 Economic and Environmental Principles and Guidelines for Water and Related Land Resources Implementation Studies. Electronic document, https://planning.erdc.dren.mil/toolbox/library/Guidance/Principles_ Guidelines.pdf, accessed April 4, 2020.

Yoe, Charles E.

2012 Principles of Risk Analysis: Decision Making under Uncertainty. CRC Press, Boca Raton, Florida.

Yoe, Charles E., and Kenneth D. Orth

1996 Planning Manual. IWR Report 96-R-21. U.S. Army Corps of Engineers, Institute for Water Resources. Electronic document, https://www.iwr.usace. army.mil/Portals/70/docs/iwrreports/96r21.pdf, accessed July 13, 2020.

Zoccola, Michael F., and Fabio Santillan

20132013 OPA Winner: Wolf Creek Dam Rehabilitation. Deep Foundations September/October:12-15. https://html5.dcatalog.com/?docid=af9fdd53f86f-496c-b96f-a22600dd9e6d, accessed July 13, 2020.

\section{AUTHOR INFORMATION}

Valerie J. McCormack $\square$ U.S. Army Corps of Engineers, Nashville District, 110 Ninth Avenue South, Nashville, TN 37203, USA (valerie.j.mccormack@usace. army.mil, corresponding author)

Kary Stackelbeck - Oklahoma Archeological Survey, University of Oklahoma, 111 East Chesapeake, Norman, OK 73019-5111, USA 